\title{
Sistem Pendidikan Inklusif Perspektif Neurosains
}

\author{
Ely Novianti \\ Program Studi Pendidikan Agama Islam, Universitas Ahmad Dahlan, Indonesia
}

\begin{tabular}{|c|c|}
\hline & ABSTRACT \\
\hline Article history: & Assesing inclusion education in neuroscience perspectives is particularly \\
\hline Received 2020-02-14 & $\begin{array}{l}\text { interesting. This study is a literature review. Given the development of } \\
\text { normal and special needs children have different backgrounds. Cognitive }\end{array}$ \\
\hline Accepted 2020-03-10 & $\begin{array}{l}\text { development of children are different according to parenting patterns. In this } \\
\text { case the parents need to be aware of the type of child and need to understand }\end{array}$ \\
\hline Keywords: & $\begin{array}{l}\text { to gain knowledge and educate the individual. The background of every child } \\
\text { is not an obstacle in getting a decent education. The government and }\end{array}$ \\
\hline First Education & education authorities now have acces to the concept of inclusive education. \\
\hline Second Disable & With the application of inclusive education can expand access to education \\
\hline Third Development & $\begin{array}{l}\text { for all groups including children with disabilities. This effort is made to } \\
\text { develop the potential of intelligence, talent,and soft skills prossessed without } \\
\text { discrimination.in addition, at the age of gold, children with special needs are } \\
\text { directed to interest and talent. With experience early on hope when } \\
\text { adolescents are able to hone and can compete with normal children. This is } \\
\text { because there is already a maturity in the individual's ability and creativity. }\end{array}$ \\
\hline
\end{tabular}

\section{Corresponding Author:}

Ely Novianti,

Program studi Pendidikan Agama Islam,

Universitas Ahmad Dahlan,

Email: ely1711031136@uad.ac.id

\section{PENDAHULUAN}

Setiap manusia yang berpasangan di dunia pada hakikatnya ingin memiliki keturunan. Ketika seorang ibu mengandung terdapat pengharapan yakni anaknya terlahir sempurna tanpa ada kecacatan. Begitu pula dengan Ayah yang mengharapkan anaknya menjadi penyenang hati bagi mereka. Akan tetapi pada nyatanya tidak semua anak yang terlahir tersebut memiliki kondisi yang sempurna. Apapun kondisi anak dan tentang ketidaksempurnaan seorang anak pada prinspinya semua anak adalah bintang. Allah berfirman:

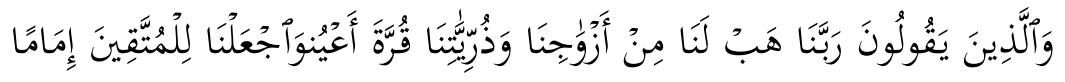

Yang artinya "Dan orang orang yang berkata: "Ya Tuhan kami, anugrahkanlah kepada kami isteri-isteri kami dan keturunan kami sebagai penyenang hati (kami), dan jadikanlah kami imam bagi orang-orang yang bertakwa."(Q.S. Al-Furqan [25] : 74).

Kita menelusuri kembali proses terjadinya manusia bahwa ratusan juta sperma bergerak berkompetisi secara sehat untuk memperebutkan dirinya menjadi sang juara untuk bertemu dengan satu telur. Ketika sperma yang meraih dengan satu telur (ovum) berhasil membuahi dialah pemenangnya dan jadilah sang buah hati. Anak-anak yang terlahir ke dunia ialah anakanak pemenang juara, merekalah anak-anak pilihan yang membawa bintangnya sejak lahir.

Sebahagian masyarakat pada fenomena masa kini Ayah atau Ibu kurang mensyukuri kenikmatan yang telah Allah SWT berikan dengan kehadiran sang buah hati. Mereka lahir 
disambut dengan celotehan orang tua berupa sikap membanding-bandingkan pribadi anak ini dengan anak yang lain. Tidak sepatutnya sebagai orang tua melakukan tindakan tersebut kepada sang buah hati. Orang tua perlu mengingat bahwasanya Allah SWT tidak pernah membuat produk gagal. Setiap fenomena dimuka bumi adalah pembelajaran orang tua agar senantiasa tak pernah berhenti belajar menuntut ilmu demi anak-anakya. Dengan adanya ilmu mereka dibekali metode yang tepat dan disesuaikan gaya belajar serta kondisi anak.

Pendidikan anak tidak terlepas dari tiga komponen yakni keluarga, sekolah, dan masyarakat. Orang tua adalah gerbang pertama untuk membina dan mendidik anaknya untuk memberikan pendidikan yang terbaik. Bahwasanya kita mengingat ungkapan "Tiada suatu pemberian yang lebih utama dari orang tua kepada anaknya, selain pendidikan yang baik." (HR. Al-Hakim). Dengan adanya sistem pendidikan yang ramah dan terbuka terhadap anak berkebutuhan khusus melalui layanan diberikan oleh pihak sekolah dapat meningkatkan kepercayaan diri mereka untuk menunjukkan kemampuannya. Oleh sebab itu, harapannya siswa yang berkebutuhan khusus diberikan pelayanan yang layak dan mendukung untuk mengembangkan kecerdasan serta minat dan bakat. Sehingga pihak sekolah dan orang tua pun akan mengetahui bahwa anak berkebutuhan khusus dapat memiliki prestasi yang gemilang seperti anak pada umumnya.

Prof. dr. Moh Hasan Machfoed,Sp.S(K), M.S Ketua Umum PERDOSSI (Persatuan dokter Spesialis Peakit Saraf Indonesia), Neuroscience adalah ilmu yang mencoba mengungkap misteri otak. Dalam perspektif neurosains otak manusia tersusun oleh 100 miliar sel otak atau neuron. Pandangan bahwa otak anak difabel dan normal berbeda. Pada kenyataannya pernyataan tersebut tidak dibenarkan. Anak-anak di seluruh dunia yang lahir tentu tidak semuanya tercipta dengan kesempurnaan. Akan tetapi hal yang tidak sempurna tersebut bukan berarti sebagai golongan yang terimaginalkan. Dengan adanya peristiwa yang menurut sebagaian pengamat anak yang memiliki latar belakang berkebutuan khusus dan difabel dirasa masih mengalami diskriminasi. Sehingga ada gugahan gerakan yang menjadi komitmen bersama negara-negara di dunia untuk memperjuangkan hak untuk memperoleh pendidikan. Bekaitan dengan adanya layanan khusus tidak terlepas dari peran UNESCO pada tahun 1994 yang mendeklarasikan ideologi pendidikan insklusif secara Internasional. Dengan adannya komitmen bahwa pendidikan untuk semua memberikan dampak yang cukup signifikan. Sehingga anak yang berkebutuhan khusus dan difabel mendapatkan perhatian dalam aspek pendidikan.

Awal mula sebuah konsep inklusi tentu tidak terlepas yang berawal dari eksklusi. Sejarah abad ke-20 anak-anak normal dengan penyandang hambatan dipisahkan dalam proses pendidikan. Pada abad tersebut eksklusi terhadap anak-anak penyandang berkebutuhan khusus sudah hal yang legal dalam setiap negara. Terdapat sebuah kasus yang menjadi titik balik dalam dunia pendidikan yakni kasus Pennsylvania di Amerika Serikat. Dimana kasus ini orangtua anak-anak penyandang hambatan mental meminta keadilan. mereka meminta hak untuk anak yang mengalami hambatan dapat merasakan disekolah umum. Sehingga pada tahun 1971 kasus tersebut ditangani oleh Pengadilan distrik yang kemudian mengeluarkan kebijakan. Kebijakan tersebut membahas terkait bahwa anak-anak penyandang kebutuhan khusus tidak boleh ditolak pendidikannya karena hambatan mereka tanpa melalui proses hukum. Dengan demikian, hal yang utama dalam menangani permasalahan tersebut adalah mengembangkan sekolah-sekolah yang terpadu. Terdapat sebuah pernyataan dalam kasus Pennsylvania Association For Relarded Children bahwa "penempatan di kelas khusus sekolah reguler dianjurkan dibanding di kelas sekolah umum".

Dengan adanya sebuah kasus tentu ada kesadaran untuk membentuk kebijakan dalam rangka menumbuhkan kesadaran bagi masalah para penyandang hambatan. Pada tahun 1975 terdapat sebuah kongres dimana Education of All Handicapped Children Act (Public Law 94142), mengeluarkan mandat bahwa layanan pendidikan yang layak diberikan bagi seluruh anak berkelainan, dan akan diberikan dana bagi penerapan layanan pendidikan tersebut. Selain Public Law 94-142 juga terdapat dasar Undang-undang lain yang mengenai inklusi seperti IDEA dan bagian 504 UU Rehabilitasi tahun 1973. Didalam bagian UU 504 ini membahas berkaitan melarang diskriminasi individu-individu yang memiliki hambatan bahkan mendorong penggabungan siswa-siswa ke dalam program dan kelas reguler.

Tidak perlu dikhawatirkan bagi penyandang disabilitas terkait pendidikan dalam sistem 
inklusif sudah mengatur hukum federal yakni peraturan perundangan federal pendidikan khusus yang disebut sebagai Individuals with Disabilities Education Act (IDEA). Awal mula undangundang ini disahkan sebagai Education for All Handicapped Children Act (EHCA) Public Law 94-142 pada 1975. Didalam peraturan hukum tersebut berisi tentang kategori disabilitas yang menjadi landasan untuk menetapkan kelayakan seorang siswa atas pendidikan khusus sekaligus menguraikan macam-macam layanan yang berhak diperoleh untuk siswa.

Sedangkan di Indonesia awal mula muncul pendidikan inklusif terjadi ketika sistem pendidikan segregasi kurang mampu memberikan perubahan dan kurang memenuhi kebutuhan bagi anak-anak berkebutuhan khusus. Pendidikan ini sebenarnya sudah ada sejak tahun 1960-an yang ditandai dengan berhasil diterimanya lulusan SLB Tunanetra di bandung masuk ke sekolah umum, meskipun ada upaya penolakan dari pihak sekolah. Lambat laun terjadi perubahan paradigma masyarakat dan sekolah umum sudah mulai terbuka dengan bersedia menerima siswa tunanetra.

Pada akhir tahun 1970-an pemerintah mulai andil terhadap anak yang berkebutuhan khusus dengan membantu membangun pendidikan integrasi dengan tujuan agar mereka dapat beradaptasi dalam lingkungan. Perhatian tersebut dibuktikan dengan menerbitkan surat persetujuan tentang perlunya merancang sistem pendidikan inklusif bagi anak berkebutuhan khusus. Rancangan tersebut berhasil dan mendorong penertiban Surat Keputusan Menteri Pendidikan nomor 002/U/1986 tentang Pendidikan Terpadu bagi anak difabel. Sayangnya, pendidikan integrasi dalam penerapannya semakin kurang diimplimentasikan terutama di jenjang SD yang disebabkan berakhirnya proyek. Perhatian pemerintah tidak berhenti sampai disitu saja, mereka ada upaya baru untuk mengembangkan pendidikan inklusif. Kebangkitan pada tahun akhir 1990-an proyek dirintis kembali dengan bekerjasama antara Depdiknas dan pemerintah Nowergia dibawah manajemen Braillo Norway dan Direktorat PLB (Tarsidi,2007). Dalam perkembangannya pendidikan inklusi di Indonesia saat ini berkembang pesat dan diterima masyarakat. Namun, dalam pelaksanaan implementasinya masih dihadapkan dengan berbagai problema terutama kurangnya tenaga pendidik profesional untuk mereka. Oleh sebab itu perlu adanya komitmen tinggi dan kerjasama dengan berbagai pihak untuk membangun pendidikan inklusif yang sesuai dengan konsep-konsep yang telah dirancang. Dengan demikian diharapkan anak-anak berkebutuhan khusus dapat sejahtera dengan cara memperoleh haknya dalam pendidikan dan merealisasikan keinginan mereka serta mendorong untuk mengembangkan diri.

\section{METODE}

Artikel ini dalam menyajikan menggunakan reserach library yakni telaah buku.

\section{HASIL PENELITIAN}

\section{Pendidikan Inklusif}

Pendidikan Inklusif merupakan konsep pendidikan yang tidak membeda-bedakan latar belakang kehidupan anak karena keterbatasan fisik maupun mental. Pemaparan pengertian tersebut menunjukkan bahwa anak yang berkebutuhan khusus dapat menjalani pendidikan bersama anak normal pada umumnya. Adapun jenis-jenis anak berkebutuhan khusus seperti anak difabel, anak tunagrahita (Keterbelakangan Mental), anak autis, anak ADHD (Attention Deficit Hyperactivity Disorder), anak tunalaras, anak superior, anak gifted (berbakat), dan anak Genius. Dari berbagai jenis macam anak berkebutuhan khusus dalam sistem layanan inklusif mereka berhak mendapatkaan pendidikan di sekolah reguler yang terdekat bersama teman sebayanya. Dengan adanya hal tersebut memberikan peluang bagi anak yang berkebutuhan khusus untuk mengembangkan potensinya secara optimal.

Memahami praktik inklusif terdapat suatu filosofi yang didasarkan pada tiga dimensi yakni sebagai berikut: Integrasi fisik: Penempatan siswa di ruangan yang sama dengan siswa bukan penyandang disabilitas harus menjadi prioritas utama. Mengeluarkan mereka dari ranah ini hanya boleh dilakukan jika memang diperlukan. Meskipun demikian, penting untuk memahami bahwa insklusivitas tidak berarti seluruh siswa harus berada dalam ranah pendidikan umum sepanjang waktu. Praktik yang demikian justru akan merugikan siswa serta melanggar kebijakan IDEA. 
Integrasi sosial : relasi antara siswa penyandang disabilitas dengan teman sekelasnya, teman sebaya lainnya, dan juga orang dewasa tetap harus dipelihara. Integrasi pengajaran : sebagaian besar siswa harus diajarkan kurikulum yang sama dengan yang digunakan untuk siswa bukan penyandang disabilitas. Akan tetapi mereka harus dibantu supaya dapat berhasil dengan cara menyesuaikan rancangan cara belajar-mengajar. Adapun ciri-ciri khusus sekolah inklusif yang perlu diterapkan oleh pendidik bagi para penyandang disabilitas, hal ini sebagai berikut (Marilyn Friend dan William D. Bursuck, 2015 : 34). Setiap orang yang bekerja disekolah berkomitmen untuk membantu seluruh siswa agar dapat mencapai potensi mereka; inklusivitas dapat dipahami sebagai suatu sistem keyakinan pada tingkat sekolah. Kepala sekolah merupakan pihak pendukung vokal yang kuat bagi seluruh siswa, yang bersikukuh agar mereka dapat mengakses kurikulum umum dengan sistem dukungan disekitar mereka. Para profesional dan staf lainnya secara rutin menggunakan bahasa yang sopan dan "manusiawi" (contohnya, memilih penyebutan siswa penyandang disabilitas daripada siswa cacat).

Penekanan ada pada kemampuan, bukan ketidakmampuan. Pendidikan khusus dan layanan lainnya tanpa kelim (seamless) - manfaat bagi siswa dimaksimalkan dan biaya yang dibebankan siswa diminimalkan (misalnya waktu istirahat diluar kelas pendidikan umum dikurangi). Pendidikan khusus dan layanan lainnya yang tidak eksis sebagai suatu kesatuan yang terpisah. Pembelajaran dirancang khusus yang dibutuhkan siswa penyandang disabilitas dapat ditawarkan baik dalam ranah pendidikan umum maupun ranah pendidikan khusus. Perbedaan dianggap sebagai tatanan (kaidah) yang berlaku, bukan pengecualian. Bantuan teknologi meningkatkan akses terhadap kurukulum umum.

Orangtua bukan hanya dianggap sebagai partner yang baik disekolah, namun juga diharapkan keikutsertaan dalam kerja samanya. Terdapat sejumlah lokasi pembelajaran yang tersedia bagi siswa, termasuk ranah terpisah namun hal ini merupakan pilihan terakhir dan hanya digunakan jika terdapat data yang mendukung efektivitasnya. Inklusivitas dapat dikomunikasikan melalui banyak cara, mulai dari materi yang ditampilkan, buku dan media lainnya, jadwal, tugas, interaksi antara orang dewasa dengan sisw atau antara satu sama lainnya dan masih banyak lagi. Inklusi jarang diperlukan karena merupakan bagian utuh dari budaya sekolah.

\section{Butir-butir kesepakatan layanan kekhususan pada Konferensi UNESCO tahun 1994}

Pernyataan Salamanca didalam konferensi UNESCO 1994: Hak semua anak termasuk didalamnya mereka yang memerlukan penyesuaian pendidikan baik sementara maupun menetap di sekolah. Hak semua anak untuk bersekolah ditempat terdekat pada kelas inklusif. Hak semua anak untuk berpartisipasi dalam pendidikan yang berpusat pada anak yang sesuai dengan kebutuhan individu. Semua mereka yang terlibat akan memperoleh pengayaan dan keuntungan melalui implementasi pendidkan inklusif. Hak semua anak untuk berpartisipasi dalam pendidikan yang berkualitas dan bermakna untuk setiap individu. Keyakinan bahwa pendidikan inklusif akan mengarah pada masyarakat inklusif dan pada akhirnya pada efektifitas biaya.

\section{Layanan Pendidikan Sistem Segregatif dan Integrative}

Sistem segregasi adalah sistem pengejaran yang memisahkan penyelengaraan pendidikan dengan anak penyandang disabilitas dan normal. Salah satu contoh layanan pendidikan sistem segresi ini adalah SLB (sekolah luar biasa). Dalam SLB memiliki jenjang yang sama pada sekolah umumnya, yakni mulai dari sekolah dasar hingga sekolah menengah atas. Kurikulum yang diberikan pun relatif sama dengan sekolah umum. Akan tetapi hal yang membedakan dengan sekolah umum yaitu tata cara penilaian akademik diserahkan dengan tingkat kemampuan tiap peserta didik dan sarana prasarana yang disediakan tiap SLB. Kelemahan dari sistem layanan segregatif diantaranya aspek perkembangan sosial dan emosi anak kurang luas karena lingkungan pergaulan yang terbatas.

Adapun terkait pendidikan khusus sudah diatur didalam Undang-Undang Nomor 20 Tahun 2003 tentang Sistem Pendidikan Nasional terutama pasal 5 ayat (2) bahwa warga negara yang memiliki kelainan fisik, emosional mental, intelektual, dan/atau sosial berhak memperoleh pendidikan khusus dan pasal 32 ayat (1) bahwa pendidikan khusus merupakan pendidikan bagi peserta didik yang memiliki tingkat tingkat kesulitan dalam mengikuti proses pembelajaran karena kelainan fisik, emosional, mental, sosial, dan/atau memiliki potensi kecerdasan dan bakat istimewa. Mengingat sudah terdapat aturan dan kebijakan pemerintah pun menyediakan fasilitas-fasilitas pendidikan untuk membantu para ABK dengan kekurangan fisik. Adapun pembagian layanan pendidikan sekolah luar biasa (SLB) yang telah disesuaikan berdasarkan kekhususan kekurangan fisiknya, diantaranya sebagai berikut :

SLB A : sekolah untuk penyandang tunanetra.

SLB B : sekolah untuk penyandang tunarungu.

SLB C : sekolah untuk penyandang tunagrahita.

SLB D : sekolah untuk penyandang tunadaksa. 
SLB E : sekolah untuk penyandang tunalaras.

SLB G : sekolah untuk penyandang cacat ganda.

Berikut ini adalah fasilitas dan sarana dalam layanan pendidikan segregatif yakni : 1). Tersedia alatalat bantu belajar yang khusus untuk siswa, misalnya bacaan dan tulisan tulisan braille, alat bantu hitung taktual, peta timbul, buku bersuara, mesin baca kurzweil, keyboarding, dan sebagainya; 2). Jumlah siswi dalam kelas tidak lebih dari delapan orang sehingga guru dapat memberikan layanan setiap individu; 3 ). Lingkungan sosial ramah karena memiliki pemahaman yang tepat mengenai disability anak; 4). Anakanak berkebutuhan khusus dapat dipertemukan dengan orang disability yang sudah sukses untuk dijadikan motivasi.

Sementara terdapat sistem integrasi atau dapat dikatakan dengan pendidikan terpadu. Sistem pendidikan integrasi ini cenderung memberikan kesempatan kepada anak yang berkebutuhan khusus untuk belajar bersama anak normal disekolah umum atau biasa. Dengan adanya layanan terpadu membuka peluang sekolah reguler memberikan fasilitas sistem layanan inklusif. Hal ini merupakan cara efektif untuk mewujudkan bahwa pendidikan hak bagi semua yang dapat menghilangkan sikap diskriminatif dan menciptakan masyarakat yang ramah. Konsep pendidikan integratif memiliki bermacam-macam penafsiran, diantaranya yakni : 1). Menempatkan anak disability dengan anak normal secara penuh; 2). Pendidikan yang berupaya mengoptimalkan perkembangan kondisi, emosi, jasmani, intuisi; 3). Mengintegrasikan apa yang di pelajari disekolah dengan tugas masa depan; 4). Mengintegrasikan manusia sebagai makhluk individual sekaligus makhluk sosial.

\section{Pengembangan Kognitif Siswa Berkebutuhan Khusus}

Pernah diketahui hasil penelitian oleh (Baker, kame'enui, Simmons, \& Simonsen, 2010) dinyatakan bahwa banyak siswa termasuk yang berkebutuhan khusus mengalami kesulitan dalam memahami gagasan penting yang berkaitan dengan bidang studi. Dalam rangka membantu memahami suatu informasi dapat menggunakan advance organizer. Penggunaan bentuk tersebut berupa informasi yang ditampilkan secara verbal atau visual agar mudah dipahami dan cukup efektif bagi siswa berkebutuhan khusus. Anak-anak tersebut yang kemungkinan memiliki keterbatasan dalam pengetahuan dasar dan pemahaman dapat juga pendidik mengarahkan dengan menampilkan peta konsep yang pada umumnya memuat identifikasi topik, garis besar isi, dan latar belakang informasi.

Pada umumnya orang tua maupun guru menginginkan untuk menciptakan generasi berkualitas. Meski dalam keterbatasan bukan penghalang mencapai keberhasilan dalam bidang pendidikan. Karena adanya kemauan orang tua sejak dini telah mengetahui perencanaan khusus untuk anaknya yang berkebutuhan khusus. Mengingat temuan neurosains dalam (Suyadi, 2017 : 31) mengenai anak ketika lahir sel-sel otaknya mencapai 100 miliar. Pengoptimalan otak pada anak-anak tersebut perlu dilakukan dengan adanya pengulangan-pengulangan tindakan seperti belajar isyarat bagi tuna rungu dan wicara dengan harapan mampu berkomunikasi dan bersosialisasi pada lingkungan umum.

Dalam mensukseskan hal tersebut seorang pendidik perlu memiliki pengetahuan neurosains agar memudahkan saat pembelajaran. Tujuan utama neurosains bagi pendidik yakni mampu menggambarkan perilaku peserta didik dari sudut aktivitas yang terjadi pada otaknya. Selain itu, neurosains mampu menjembatani anak dan guru dalam pemetaan. Pemetaan tersebut berkaitan bakat dan minat anak, yang dapat diarahkan dengan mudah oleh guru. Dengan demikian tidak hanya mengembangkan secara kognitif, namun aspek lain juga sangat berperan, seperti; afektif dan psikomotorik.

Inteligensi pada anak tunarungu diketahui secara potensial sama seperti anak normal. Namun secara fungsional perkembangan diri anak tersebut dipengaruhi tingkat kemampuan berbahasanya, informasi yang diterima terbatas, dan daya abstraksi anak. Mengingat perkembangan kognitif anak tunarungu sangat dipengaruhi oleh perkembangan bahasa, sehingga tingkat kemampuan bahasa mempengaruhi inteligensi anak tersebut. Pernyataan bahwa anak tunarungu memiliki inteligensi rendah merupakan pernyataan yang salah. Kerendahan tingkat inteligensi anak tersebut bukan faktor hambatan intelektual melainkan inteligensinya tidak mendapat kesempatan untuk berkembang.

Andreas Dwidjosumarto (1990:1) mengemukakan bahwa tunarungu ialah seseorang yang kurang mampu mendengar suara. Ketunarunguan ini dibedakan menjadi dua kategori yaitu tuli (deaf) dan kurang dengar (low of hearing). selain itu, Mufti Salim (1984 : 8) berpendapat bahwa anak tunarungu adalah anak yang mengalami kekurangan atau kehilangan kemampuan mendengar yang disebabkan oleh kerusakan atau tidak berfungsinya sebagian atau seluruh alat pendengaran sehingga ia mengalami hambatan dalam perkembangan bahasanya. Tunarungu memiliki dua pembagian spesifikasi yakni secara etiologis dan menurut tarafnya. Klasifikasi secara etiologis ketunarunguan memiliki beberapa faktor diantaranya: 1) Pada saat sebelum dilahirkan. a. salah satu atau kedua orang tua anak menderita tunarungu atau mempunyai gen sel pembawa sifat abnormal. b. sewaktu ibu mengandung terserang suatu penyakit, terutama penyakit yang diderita pada saat kehamilan tri semester pertama yakni pada saat pembentukan 
ruang telinga. c. keracunan obat-obatan; pada saat kehamilan ibu mengonsumsi obat-obat terlalu banyak atau mengkonsumsi alkohol. Hal tersebut dapat menyebabkan ketunarunguan.

2) Pada saat kelahiran. a. sewaktu melahirkan, ibu mengalami hambatan sehingga dalam persalinan dibantu dengan penyedotan (tang). b. prematuralis, yakni bayi yang lahir sebelum waktunya.. 3) Pada saat kelahiran. a. ketulian yang terjadi karena infeksi, misalnya pada otak (meningitis) atau infeksi umum seperti difteri, morbili, dan lain-lain. b. pemakaian obat-obatan ototoksi pada anak-anak. c. karena kecelakaan yang mengakibatkan kerusakan alat pendengaran bagian dalam, misalnya jatuh. Sedangkan menurut tarafnya dapat diketahui pendapat Andreas Dwidjosumarto (1990:1) mengemukakan: Tingkat I, penderita hanya memerlukan latihan berbicara dan bantuan mendengar secara khusus. Penderita pada tigkat ini kehilangan kemampuan mendengar antara 35 sampai dB. Tingkat II, kehilangan kemampuan antara 55 sampai $69 \mathrm{Db}$, penderita biasanya ditempatkan sekolah khusus dan memerlukan latihan berbicara dan bantuan latihan berbahasa secara khusus. Tingkat III, kehilangan kemampuan mendengar antara 70 sampai $89 \mathrm{~dB}$. Tingkat IV, kehilangan kemampuan mendengar $90 \mathrm{~dB}$ ke atas.

\section{Optimalisasi Otak dalam Sistem Pendidikan Inklusi}

Optimalisasi otak merupakan upaya menggunakan seluruh bagian otak secara bersama-sama dengan melibatkan sebanyak mungkin indra secara serentak. Namun bagi siswa yang mengalami kehambatan dalam organ tertentu pengoptimalan otak mengalami terkendala. Akan tetapi ada pengecualian yakni faktor internal dan eksternal. Faktor internal disini ialah motivasi semangat dalam diri anak dan senang untuk melibatkan dirinya ketika pembelajaran meski mengalami keterbatasan dalam alat penginderaan atau fisik, dan lainnya. Sedangkan faktor eksternal adalah dukungan keluarga dan lingkungan untuk tidak mengucilkan anak untuk bertumbuh kembang dengan baik serta memberi hak pendidikan dan pelayanan khusus yang baik.

Pendidikan merupakan suatu proses ketika kemampuan manusia (bakat dan kemampuan yang diperoleh) hendak dikembangkan secara terus menerus. Bakat dan kemampuan anak dalam pertumbuhannya memiliki faktor pendukung mengenai hal tersebut. Dalam pandangan ahli psikologi faktor-faktor itu sesuai pendapat aliran yakni nativisme, empirisme, dan konvergensi. Menurut aliran nativisme perkembangan individu dapat ditentukan faktor-faktor yang dibawa sejak lahir. Pandangan tersebut biasa disebut dengan "pesimisme pendagogis". Apabila kita kaitkan dengan anak yang difabel sejak dilahirkan tentu anak merasa dirinya sudah mengalami keputus asaan. Padahal didalam keterbatasan diri manusia ada sesuatu kelebihan. Dimana kelebihan itu dapat diasah dan dilatih sejak dini oleh orang tua. Setelah dilingkungan keluarga memiliki aspek yang bagus secara otomatis dilingkungan pun ia dapat mengembangkan secara optimal.

Berbeda dengan aliran empirisme yang berlawanan dengan aliran nativisme. Aliran empirisme cenderung pada optimisme paedagogis. Doktrin aliran ini menekankan bahwa perkembangan manusia itu berasal dari lingkungan, pengalaman, dan pendidikan. Kesuksesan belajar anak dalam pendidikan inklusi salah satunya dipengaruhi faktor lingkungan. Dalam hal ini termasuk alat media peraga pembelajaran untuk memudahkan dalam menyampaikan ilmu. Media pendidikan adalah suatu benda yang dapat diindrai, khususnya penglihatan dan pendengaran (alat peraga pengajaran) baik yang terdapat di dalam maupun diluar kelas yang digunakan sebagai alat bantu penghubung (medium komunikasi) dalam proses interaksi belajar-mengajar untuk meningkatkan efektifitas hasil belajar siswa. Media pendidikan ini mengandung aspek-aspek seperti alat dan teknik yang berkaitan erat dengan metode mengajar. Misalnya dicontohkan teknik yang diberikan guru untuk anak tuna rungu diantaranya; 1) Berusaha memberikan tempat duduk yang istimewa bagi anak. Hindarkan tempat yang gaduh atau yang menimbulkan efek getaran; 2) Berikan anak kesempatan untuk berekspresi dan berkomununikasi sesuai kemampuan; 3) Usahakan mengulang pertanyaan atau pernyataan apabila kurang dipahami anak; 4) Tekankan ucapan yang jelas; 5) periksa ekspresi anak sebelum berbicara kepada anak.

Sementara konvergensi merupakan gabungan antara aliran empirime dan nativisme. Dimana pembawaan dan lingkungan sangat berpengaruh terhadap pertumbuhan peserta didik. Louis William Stern sebagai tokoh utama aliran ini menganggap bakat itu sudah ada dalam diri manusia dan dikembangkan dalam lingkup lingkungan. setiap anak seharusnya memiliki bakat dan kemampuan masing-masing. Namun adapula sebagian peserta didik yang merasa belum memiliki bakat. Sehingga untuk menemukan bakat di jati dirinya peserta didik mencoba-coba segala hal sesuai minat. Sebagian pula ada yang merasa sudah memiliki bakat namun merasa belum matang bakatnya. Kematangan disini melibatkan beberapa hal diantaranya; 1) Perlengkapan dan pertumbuhan fisiologiss, termasuk kelengkapan pribadi tubuh, alat-alat indra, dan kapasitas intelektual; 2) Motivasi: menyangkut kebutuhan, minat, serta tujuan-tujuan individu untuk mempertahankan serta mengembangkan diri. Namun bagi peserta didik difabel juga memiliki kesempatan yang sama dengan penanganan yang khusus dan teknik 
yang berbeda juga.

Dengan demikian dapat disimpulkan bahwa setiap anak adalah istimewa dengan keunikan masingmasing. Mereka memiliki hak yang sama namun teknik pengajaran yang berbeda sesuai kemampuan dan kebutuhan. Pengarahan orang tua berperan penting agar memudahkan anak dalam minat dan bakat. Sehingga ketika dewasa anak sudah menemukan jati diri dirinya dan secara kematangan emosional berkembang dan menerapkan dengan baik.

\section{KESIMPULAN}

Pendidikan Inklusif di Indonesia sudah berkembang dari tingkat dasar sampai tingkat universitas. Mereka memberi pelayanan-pelayanan khusus untuk penyandang disabilitas agar berhasil di kelas inklusif dan mengikuti dengan baik. Layanan yang dapat diterima oleh siswa penyandang disabilitas diantaranya pendidikan khusus, layanan terkait, serta bantuan dan jasa pelengkap. Dengan adannya akses ini juga harus diimbangi dengan tenaga yang profesional dan bertanggungjawab. Dukungan perilaku positif masyarakat terhadap mereka sangat dibutuhkan agar mereka merasa tidak terimaginalkan. Jangan sampai mereka di diskriminasi karena mereka juga membutuhkan bersosialisasi dengan teman sebayanya. Dengan demikian kita juga perlu memahami dan menyadari pentingnya pendidikan inklusif. Sebagai pengajar yang berkualifikasi dalam bidang ini diharapkan mampu memberikan dorongan dan motivasi agar sukses di sekolah dengan sistem inklusif.

Sekolah inklusi menjadi unsur budaya sekolah yang tidak kasat mata. Menerapkan pandangan pendidikan adalah hak semua anak maka perlu adanya dukungan perilaku positif masyarakat terhadap anak berkebutuhan khusus agar mereka merasa tidak terimaginalkan. Jangan sampai mereka di diskriminasi karena mereka juga membutuhkan akases belajar dan bersosialisasi dengan teman sebayanya. Dengan demikian kita juga perlu memahami dan menyadari pentingnya pendidikan inklusi. Sebagai pengajar yang berkualifikasi dalam bidang ini diharapkan mampu memberikan dorongan dan motivasi agar sukses di sekolah dengan sistem inklusi. Dalam perspektif neurosains membuka pandangan guru tidak hanya membekali materi namun ia juga bertanggung jawab atas pengoptimalan kecerdasan peserta didik. Pada hakikatnya guru setiap hari mengubah otak peserta didik dengan memberikan pengajaran sesuai tingkatan pendidikan dan mengembangkan potensi yang ada didalam individu. Melalui pendidikan inilah yang menjadi penghantar kesuksesan di maa depan dalam rangka mencapai impian peserta didik.

\section{REFERENSI}

Azwar, Saifuddin. (Edisi ke-8 2011). Pengantar Psikologi Inteligensi. Yogyakarta: Pustaka Pelajar

Baharuddin. (Edisi Ke-2 2017). Pendidikan dan Psikologi Perkembangan. Yogyakarta: Ar-Ruzz Media

Daradjat, Zakiah. (Edisi ke-6 2014). Metodik Khusus Pengajaran Agama Islam. Jakarta: Bumi Aksara

Friend,Marlynd dan William D. Bursuck.(2015), Menuju Pendidikam Inklusi Panduan Praktis untuk Mengajar. Edisi Ke 7. Diterjemahkan Oleh Annisa Nuriowandari. Yogyakarta: Pustaka Pelajar

Ilahi, Mohammad Takdir, (2013). Pendidikan Inklusif: Konsep dan Aplikasi, Yogyakarta: AR-RUZZ Media

Pratiwi, Ratih Putri dan Afin Murtiningsih. (2013). Kiat Sukses Mengasuh Anak Berkebutuhan Khusus, Yogyakarta: AR-RUZZ MEDIA

P,Dayu. A. (2010), Mendidik Anak ADHD (Attention Deficit Disorder) Hal-hal yang Tidak Bisa dilakukan Obat, Yogyakarta: javalitera

Smith,David J. (2009). Inklusi Sekolah Ramah untuk Semua. Edisi ke 2. Diterjemahkan Oleh :Ny Enrica. Bandung: Penerbit Nuansa

Suyadi. (Edisi ke-4 2017). Teori Pembelajaran Anak Usia Dini, Bandung: PT Remaja Rosdakarya Offset

Somantri, Sutjihati. (2012). Psikologi Anak Luar Biasa, Bandung: PT Refika Aditama

https://dokumen.tips/documents/sejarah-atau-latar-belakang-layanan- pendidikan-luar-biasa-finish.html (Diakses pada 30 November 2017, Jam 13.30) 